\title{
ANALISIS RASIO KEUANGAN UNTUK MENGUKUR KINERJA KEUANGAN PEMERINTAH DAERAH KOTA MATARAM
}

\author{
Hery Susanto ${ }^{1}$ \\ ${ }^{1}$ Fakultas Ekonomi Universitas Terbuka, Mataram, herys@ecampus.ut.ac.id
}

\begin{abstract}
ABSTRAK
Analisis rasio keuangan terhadap Anggaran Pendapatan dan Belanja Daerah (APBD) merupakan salah satu parameter dalam pengukuran kinerja pengelolaan keuangan daerah. Analisis kinerja keuangan menggunakan perhitungan rasio efektifitas, efisiensi, kemandirian keuangan daerah, aktifitas dan pertumbuhan. Penelitian ini bertujuan untuk mengukur kinerja keuangan Pemerintah Daerah Kota Mataram selama kurun waktu Tahun Anggaran 2012-2015. Jenis penelitian yang digunakan adalah deskriptif menggunakan metode analisis rasio. Hasil penelitian menunjukkan bahwa, rasio efektifitas dikategorikan efektif, rasio efisiensi dikategorikan tidak efisien, rasio kemandirian pengelolaan keuangan daerah masih rendah, rasio aktifitas kurang baik, rasio pertumbuhan pada komponen Pendapatan Asli Daerah (PAD) kurang baik, sementara pada komponen rasio pendapatan daerah dikategorikan sedang, untuk pertumbuhan belanja dikategorikan kurang baik karena porsi belanja operasi lebih besar dari belanja modal. Diharapkan Pemerintah Daerah Kota Mataram dapat lebih meningkatkan PAD, serta melakukan skala prioritas alokasi belanja daerah.
\end{abstract}

Kata kunci: kinerja keuangan, aktifitas, pertumbuhan

\section{ABSTRACT}

Financial ratio analysis to Regional Revenue and Expenditure Budget (APBD) is one of the parameters in measuring the performance of regional financial management. Analysis of financial performance using the calculation of the effectiveness ratio, efficiency, local financial independence, activity and growth. This study aims to measure the financial performance of the Regional Government of Mataram during the period of Fiscal Year 2012-2015. The type of research used is descriptive using ratio analysis method. The results showed that the effectiveness ratio was categorized as effective, the efficiency ratio was categorized as inefficient, the independence ratio of local financial management was still low, the ratio of bad activity, the ratio of growth in the component of local revenue (PAD) was less good, while the component of the ratio of regional income was categorized, for the growth of expenditure is categorized as less good because the portion of operating expenditure is bigger than capital expenditure. It is expected that the Local Government of Mataram can increase PAD more, and make priority scale of allocation of regional expenditure.

Keywords: financial performance, effectiveness, efficiency, independence, growth

\section{PENDAHULUAN}

Pengukuran kinerja keuangan daerah bertujuan untuk menilai akuntabilitas maupun efektifitas pengelolaan anggaran sehubungan aktifitas pelayanan publik. Penilaian akuntabilitas tersebut, bukan hanya semata berbicara mengenai bagaimana pemerintah daerah mampu menyerap serta menggunakan anggaran, namun terlebih pada bagaimana pengalokasian anggaran tersebut telah sesuai dengan perencanaan yang telah ditetapkan sebelumnya sesuai kaidah prinsip pengalokasian anggaran yang efektif, efisien serta ekonomis. 
Menurut kamus akuntansi manajemen, Kinerja (performance) diartikan sebagai aktivitas terukur dari suatu entitas selama periode tertentu sebagai bagian dari ukuran keberhasilan pekerjaan. Pengukuran kinerja diartikan sebagai suatu sistem keuangan atau non keuangan dari suatu pekerjaan yang dilaksanakan atau hasil yang dicapai dari suatu aktivitas, suatu proses atau suatu unit organisasi. Sementara, kinerja keuangan pemerintah daerah adalah tingkat pencapaian dari suatu hasil kerja di bidang keuangan daerah yang meliputi penerimaan dan belanja daerah dengan menggunakan sistem keuangan yang ditentukan melalui suatu kebijakan atau ketentuan perundangundangan selama satu periode anggaran. Bentuk dari pengukuran kinerja tersebut berupa rasio keuangan yang terbentuk dari sistem laporan pertanggungjawaban daerah berupa perhitungan APBD.

Peraturan Pemerintah Republik Indonesia Nomor 71 Tahun 2010 Tentang Standar Akuntasi Pemerintahan merupakan instrumen dan tata tertib yang mengatur mengenai mekanisme dan standar pengelolaan keuangan serta pelaporan keuangan pemerintah daerah. Peraturan Pemerintah tersebut menjadi acuan bagi pemerintah daerah dalam menyajikan laporan keuangan yang memberikan informasi yang relevan mengenai posisi keuangan serta transaksi selama satu periode tahun anggaran.

Penyajian laporan keuangan bertujuan untuk mengetahui pemanfaatan sumber daya ekonomi untuk pelaksanaan kegiatan operasional pemerintahan, menilai kondisi keuangan pemerintah daerah, melakukan evaluasi terhadap efektifitas dan efisiensi pelaksanaan program, serta memastikan ketaatan penyajian serta kesesuaian penyajian laporan menurut kaidah peraturan perundang-undangan. Berdasarkan hal tesebut masalah dalam penelitian ini adalah "Bagaimanakah kinerja keuangan Kota Mataram ditinjau dari efektivitas, efisiensi, kemandirian, aktivitas dan pertumbuhan”?

\section{TINJAUAN LITERATUR}

\section{Parameter Rasio Keuangan Pemerintah Daerah}

Susanto (2015), mengatakan bahwa kondisi kesehatan keuangan pemerintah daerah dapat dinilai dengan cara menganalisis rasio keuangan berdasarkan informasi laporan keuangan. Penyusunan laporan keuangan pemerintah merupakan perwujudan dari transparansi dan akuntabilitas pengelolaan keuangan negara.

Penggunaan analisis rasio difokuskan pada Anggaran Pendapatan dan Belanja Daerah (APBD), yakni dengan cara membandingkan hasil yang dicapai dari satu periode dibandingkan dengan periode sebelumnya, sehingga dapat diketahui bagaimana kecenderungan yang terjadi. Disamping itu dapat pula dilakukan pengukuran dengan cara membandingkan rasio keuangan yang dimiliki oleh suatu pemerintah daerah tertentu dengan daerah lain yang memiliki potensi daerah relatif sama untuk mengetahui bagaimana rasio keuangan pemerintah daerah tersebut terhadap pemerintah daerah lainnya.

Badan Penelitian dan Pengembangan Depdagri RI bekerjasama dengan FISIPOL UGM dalam Susanto (2014) mengemukakan bahwa untuk menentukan corak ekonomi daerah digunakan variabel-variabel pokok seperti: kemampuan keuangan daerah (tingkat kemandirian keuangan daerah, tingkat ketergantungan Pemerintah Daerah terhadap Pemerintah Pusat dan tingkat desentralisasi fiskal daerah), aparatur pemerintah daerah, partisipasi masyarakat, ekonomi, demografi, organisasi masyarakat dan 
penunjang, terdiri dari aspek politik dan hukum yang diukur menggunakan rasio-rasio keuangan.

Adapun rasio keuangan yang digunakan dalam kinerja Pemerintah Daerah adalah sebagai berikut :

\section{Rasio Efektifitas}

Rasio ini menggambarkan kemampuan pemerintah daerah dalam merealisasikan penerimaan yang direncanakan dibandingkan dengan target PAD yang ditetapkan berdasarkan potensi riil daerah. Kemampuan daerah dikatakan efektif, jika rasio efektifitas yang dicapai minimal 100\%. Semakin tinggi, semakin baik. Secara umum, nilai efektifitas PAD dapat dikatagorikan sebagai berikut;

Tabel 1. Kriteria Kinerja Pengelolaan Keuangan Daerah

\begin{tabular}{|c|c|}
\hline Persentase Kinerja Keuangan & Kriteria \\
\hline Diatas $100 \%$ & Sangat Efektif \\
\hline $90 \%-100 \%$ & Efektif \\
\hline $80 \%-90 \%$ & Cukup Efektif \\
\hline $60 \%-80 \%$ & Kurang Efektif \\
\hline Kurang dari $60 \%$ & Tidak Efektif \\
\hline
\end{tabular}

Sumber : Tim Litbang Depdagri Fisipol UGM dalam dalam Susanto (2014)

\section{Rasio Efisiensi}

Rasio ini menggambarkan perbandingan antara besarnya biaya yang dikeluarkan atau belanja untuk memperoleh penerimaan dengan realisasi penerimaan yang diterima. Kinerja pemerintah daerah dalam melakukan pemungutan pendapatan dikatagorikan efisien apabila rasio yang dicapai kurang dari satu atau dibawah $100 \%$. Semakin kecil rasio efisiensi, berarti kinerja Pemerintah Daerah semakin baik.

Tabel 2. Kriteria Kinerja Pengelolaan Keuangan Daerah

\begin{tabular}{|c|c|}
\hline Persentase Kinerja Keuangan & Kriteria \\
\hline Diatas $100 \%$ & Tidak Efisien \\
\hline $90 \%-100 \%$ & Kurang Efisien \\
\hline $80 \%-90 \%$ & Cukup Efisien \\
\hline $60 \%-80 \%$ & Efisien \\
\hline Kurang dari $60 \%$ & Sangat Efektif \\
\hline
\end{tabular}

Sumber : Tim Litbang Depdagri Fisipol UGM dalam dalam Susanto (2014)

\section{Rasio Kemandirian Keuangan Daerah}

Kemandirian Keuangan Daerah (otonomi fiskal) menunjukkan kemampuan Pemerintah Daerah dalam membiayai sendiri kegiatan pemerintahan, pembangunan serta pelayanan kepada masyarakat yang telah membayar pajak dan retribusi sebagai sumber penerimaan yang diperlukan daerah. Kemandirian keuangan daerah, ditunjukkan melalui besar kecilnya Pendapatan Asli Daerah (PAD) dibandingkan dengan pendapatan daerah yang bersumber dari sumber lain misalnya; Bantuan Pemerintah Pusat/Provinsi maupun dari Pinjaman Daerah. Rasio kemandirian menggambarkan ketergantungan daerah terhadap sumber dana ekstern (Pemerintah 
Pusat/Provinsi). Semakin tinggi rasio kemandirian berarti tingkat ketergantungan Pemerintah Daerah terhadap bantuan pihak ekstern semakin rendah. Rasio kemandirian menggambarkan tingkat partisipasi masyarakat dalam membangun daerah. Semakin tinggi rasio kemandirian, semakin tinggi partisipasi masyarakat membayar pajak dan retribusi daerah yang merupakan komponen utama pembentuk PAD.

Tabel 3. Kriteria Penilaian Kemandirian Keuangan Daerah

\begin{tabular}{|c|c|}
\hline Persentase PAD & Kemandirian Keuangan Daerah \\
\hline $0,00-10,00$ & Sangat Kurang \\
\hline $10,00-20,00$ & Kurang \\
\hline $20,01-30,00$ & Sedang \\
\hline $30,01-40,00$ & Cukup \\
\hline $40,01-50,00$ & Baik \\
\hline$>50,00$ & Sangat Baik \\
\hline
\end{tabular}

Sumber : Tim Litbang Depdagri Fisipol UGM dalam dalam Susanto, 2014

\section{Rasio Aktifitas}

Rasio ini menggambarkan bagaimana pemerintah daerah memprioritaskan alokasi dananya pada belanja rutin (belanja operasi) dan belanja pembangunan (belanja modal) secara optimal. Semakin tinggi persentase dana yang dialokasikan untuk belanja rutin berarti persentase belanja investasi (belanja pembangunan) yang digunakan untuk menyediakan sarana prasarana ekonomi masyarakat cenderung semakin kecil.

\section{Rasio Pertumbuhan}

Rasio ini mengukur seberapa besar kemampuan Pemerintah Daerah dalam mempertahankan dan meningkatkan keberhasilan yang telah dicapainya dari periode ke periode berikutnya. Pengukuran rasio pertumbuhan ini bertujuan untuk mengukur besaran antara komponen penerimaan dan pengeluaran sehingga dapat digunakan untuk menilai potensi mana yang lebih diproritaskan untuk mendapatkan perhatian.

\section{Komponen Laporan Keuangan Pemerintah Daerah}

Peraturan Pemerintah No 71 Tahun 2010 tentang Standar Akuntansi Pemerintah mendeskripsikan laporan keuangan poko pemerintah terdiri dari :

1. Laporan Realisasi Anggaran (LRA)

2. Laporan Laporan Perubahan Saldo Anggaran Lebih (LPSAL)

3. Neraca

4. Laporan Operasional (LO)

5. Laporan Perubahan Ekuitas (LPE)

6. Laporan Arus Kas (LAK)

7. Catatan Atas Laporan Keuangan (CALK)

\section{Pengguna Informasi Rasio Keuangan}

lain :

Adapun pihak-pihak yang berkepentingan terhadap rasio keuangan APBD antara

1. DPRD sebagai wakil rakyat masyarakat. 
2. Pihak eksekutif, sebagai landasan penyusunan APBD pada Tahun Anggaran berikutnya.

3. Pemerintah Pusat/Provinsi sebagai masukan dalam membina pelaksanaan pengelolaan keuangan daerah.

4. Masyarakat dan Kreditur sebagai pihak yang akan turut memiliki saham pemerintah daerah, bersedia memberi pinjaman atau membeli obligasi.

\section{Jenis Penelitian}

Jenis penelitian yang digunakan adalah penelitian deskriptif, yakni peneliti mendatangi objek penelitian secara langsung guna memperoleh data-data maupun informasi yang mendukung pemecahan masalah penelitian.

\section{Tempat dan Waktu Penelitian}

Penelitian ini dilakukan di Kota Mataram, menggunakan data-data primer dari sumber sekunder yakni Biro Keuangan Setda Kota Mataram dan Kantor Badan Pusat Statistik (BPS) Kota Mataram. Data penelitian bersumber dari data APBD Kota Mataram Tahun Anggaran 2012 sampai dengan Tahun Anggaran 2015.

\section{METODE PENELITIAN}

Metode analisis yang digunakan pada penelitian ini adalah metode analisis deskriftif, yang bertujuan untuk menggambarkan kinerja keuangan Pemerintah Kota Mataram berdasarkan Rasio Kinerja Keuangan.

\section{a. Rasio Efektifitas}

Penghitungan efektifitas pengelolaan keuangan pemerintah daerah dirumuskan menggunakan perbandingan antara realisasi penerimaan dengan target yang ditetapkan dikalikan seratus persen.

$$
\text { Rasio Efektivitas }=\frac{\text { Realisasi Penerimaan }}{\text { Target Penerimaan }} \times 100 \%
$$

\section{b. Rasio Efisiensi}

Perhitungan efisiensi pengelolaan keuangan pemerintah daerah dirumuskan menggunakan perbandingan antara realisasi pengeluaran anggaran atau belanja dengan pendapatan/penerimaan daerah dikalikan seratus persen.

$$
\text { Rasio Rasio Efisiensi }=\frac{\text { Biaya yang dikeluarkan/Belanja }}{\text { Realisasi Penerimaan }} \times 100 \%
$$

\section{c. Rasio Kemandirian}

Perhitungan Kemandirian Keuangan Daerah dirumuskan menggunakan perbandingan antara Pendapatan Asli Daerah dengan bantuan dari pemerintah pusat atau provinsi dikali seratus persen.

$$
\text { Rasio Kemandirian }=\frac{\text { Pendapatan Asli Daerah }}{\text { Bantuan Pemerintah Pusat/Provinsi }} \times 100 \%
$$




\section{d. Rasio Aktifitas}

Perhitungan Aktifitas Keuangan Daerah dirumuskan menggunakan perbandingan antara total belanja rutin/operasi dengan Total APBD dikali seratus persen. Dan total belanja pembangunan dengan APBD dikalikan seratus persen.

Rasio Belanja Rutin terhadap APBD $=\frac{\text { Total Belanja Rutin }}{\text { Total APBD }} \times 100 \%$

Rasio Belanja Pembangunan terhadap APBD

$$
=\frac{\text { Total Belanja Pembangunan }}{\text { Total APBD }} \times 100 \%
$$

\section{e. Rasio Pertumbuhan}

Perhitungan pertumbuhan keuangan daerah dirumuskan sebagai berikut :

Persentase Pertumbuhan PAD $=\frac{\operatorname{PAD} \text { tahun } p-\operatorname{PAD} \text { tahun } p-1}{\operatorname{PAD} \text { tahun } p-1} \times 100 \%$

$\%$ Pertumbuhan total pendapatan $=\frac{\text { Pendapatan } \operatorname{Th} p-\operatorname{PAD} \operatorname{Th} p-1}{\text { Pendapatan } \operatorname{Th} p-1} \times 100 \%$

(Keterangan : Th $=$ Tahun $p=$ tahun yang dihitung, $p-1=$ tahun sebelumnya)

\section{HASIL PENELITIAN DAN PEMBAHASAN}

Dalam pembahasan hasil penelitian ini dibahas mengenai bagaimana kinerja keuangan yang telah dilaksanakan oleh Pemerintah Kota Mataram. Data yang digunakan untuk mengukur kinerja pengelolaan keuangan Kota Mataram tersebut adalah berupa Laporan Realisasi Anggaran APBD Tahun Anggaran 2012, 2013, 2014 dan 2015.

\section{Rasio Efektifitas}

Rasio efektifitas menggambarkan kemampuan pemerintah daerah dalam merealisasikan pendapatan asli daerah yang telah direncanakan dibandingkan dengan target yang telah ditetapkan berdasarkan potensi penerimaan daerah. Kemampuan daerah dalam menyelenggarakan tugas dikatagorikan efektif apabila rasio yang dicapai minimal sebesar 1 (satu) atau seratus persen. Perhitungan rasio efektifitas Pemerintah Kota Mataram adalah sebagai berikut:

Tabel 4. Efektifitas Pengelolaan Keuangan Daerah Kota Mataram TA. 2012 - 2015

\begin{tabular}{|c|r|r|c|}
\hline Tahun & \multicolumn{1}{|c|}{ Realisasi Penerimaan } & \multicolumn{1}{c|}{ Target Penerimaan } & Persentase (\%) \\
\hline 2012 & $755.277 .369 .807,29$ & $721.899 .242 .989,50$ & 104,62 \\
\hline 2013 & $865.839 .838 .811,63$ & $864.905 .445 .373,00$ & 100,1 \\
\hline 2014 & $1.083 .104 .564 .131,00$ & $1.055 .390 .821 .016,00$ & 102,63 \\
\hline 2015 & $1.188 .895 .201 .828,50$ & $1.211 .783 .220 .893,93$ & 98,11 \\
\hline
\end{tabular}

Sumber data : data diolah (2017) 
Tabel 4 menunjukkan perkembangan rasio efektifitas Kota Mataram yang cukup baik, dengan hasil rata-rata $101,85 \%$ selama kurun waktu tahun anggaran 2012-2015. Pada tahun 2012 rasio efektifitas sebesar 104,62\% dimana realisasi penerimaan lebih besar dari target penerimaan yang ditetapkan. Tahun 2013 rasio efektifitas menurun menjadi $100,10 \%$ namun realisasi penerimaan tetap mampu melampaui dari target penerimaan yang ditetapkan. Tahun 2014, terjadi peningkatan kembali terhadap rasio efektifitas menjadi 102,63\% dimana realisasi penerimaan lebih besar dari target yang ditetapkan. Namun, ada tahun 2015 terjadi penurunan rasio efektifitas menjadi 98,11\% dimana realisasi penerimaan lebih kecil dari target penerimaan yang telah ditetapkan. Kendati hasil rata-rata rasio efektifitas yang diperoleh menunjukkan katagori Sangat Efektif, namun terjadinya penurunan realisasi penerimaan harus dapat ditingkatkan pada tahun-tahun berikutnya, khususnya pada upaya optimalisasi pemungutan pajak maupun retribusi daerah yang merupakan sumber pendapatan asli daerah.

\section{Rasio Efisiensi}

Untuk memperoleh ukuran yang proporsional maka rasio efektifitas perlu diperbandingkan dengan rasio efisiensi yang dicapai oleh pemerintah. Rasio efisiensi menggambarkan besaran biaya yang dikeluarkan untuk memperoleh pendapatan dengan realisasi pendapatan yang diterima.

Kinerja keuangan pemerintah daerah dapat dikatagorikan efisisen apabila rasio yang dicapai kurang dari 1 (satu) atau dibawah seratus persen. Semakin kecil rasio efisiensi menggambarkan kemampuan keuangan daerah yang semakin baik. Perhitungan rasio efisiensi Pemerintah Kota Mataram adalah sebagai berikut:

Tabel 5. Efesiensi Pengelolaan Keuangan Daerah Kota Mataram TA. 2012 - 2015

\begin{tabular}{|c|r|r|c|}
\hline Tahun & \multicolumn{1}{|c|}{ Belanja } & \multicolumn{1}{c|}{ Realisasi Penerimaan } & Persentase (\%) \\
\hline 2012 & $740.283 .006 .976,00$ & $755.277 .369 .807,29$ & 98,01 \\
\hline 2013 & $883.521 .845 .035,00$ & $865.839 .838 .811,63$ & 102,04 \\
\hline 2014 & $1.044 .355 .803 .030,95$ & $1.083 .104 .564 .131,00$ & 96,42 \\
\hline 2015 & $1.188 .685 .851 .689,10$ & $1.188 .895 .201 .828,50$ & 99,98 \\
\hline
\end{tabular}

Sumber data : data diolah (2017)

Dari Tabel 5 menunjukan rasio efisiensi pada tahun 2012 sebesar 98,01\%, tahun 2013 sebesar 102,04\%, tahun 2014 sebesar 96,42\% dan pada tahun 2015 sebesar 99,98.

Berdasarkan hasil perhitungan rasio efisiensi Pemerintah Daerah Kota Mataram tahun anggaran 2012-2015 dikatagorikan kurang efisien dengan tingkat rata-rata pencapaian efisiensi sebesar $99,12 \%$. Pencapaian ini menggambarkan bahwa kinerja pemerintah dalam pemungutan PAD kurang efisien yang ditandai dengan trend rasio dibawah $100 \%$. Artinya untuk menghasilkan output yang optimal pemerintah daerah mengeluarkan biaya yang cukup besar. Penghematan anggaran serta pengalokasian pos-pos anggaran pembiayaan sebaiknya mempertimbgkan skala prioritas kebutuhan daerah untuk mewujudkan kinerja keuangan daerah yang yang sesuai prinsip value for money yang ekonomis, efektif dan efisien. 


\section{Rasio Kemandirian}

Rasio kemandirian keuangan daerah menggambarkan tingkat partisipasi masyarakat dalam pembangunan daerah. Semakin tinggi rasio kemandirian, semakin tinggi partisipasi masyarakat dalam membayar pajak dan retribusi daerah yang merupakan komponen utama pendapatan asli daerah. Semakin tinggi partisipasi masyarakat untuk membayar pajak dan retribusi daerah menggambarkan kesejahteraan daerah yang semakin tinggi, hal ini mengandung pengertian bahwa tingkat ketergantungan daerah terhadap bantuan Pemerintah Provinsi/Pusat akan semakin rendah. Berikut perhitungan Rasio Kemandirian Keuangan Daerah Pemerintha Kota Mataram;

Tabel 6. Kemandirian Pengelolaan Keungan Daerah Kota Mataram TA. 2012 - 2015

\begin{tabular}{|c|r|r|c|}
\hline Tahun & Pendapatan Asli Daerah & $\begin{array}{c}\text { Bantuan Pemerintah } \\
\text { Pusat/Provinsi }\end{array}$ & Persentase (\%) \\
\hline 2012 & $95.919 .779 .218,29$ & $659.357 .590 .589,00$ & 14,55 \\
\hline 2013 & $139.877 .149 .931,54$ & $725.962 .688 .880,00$ & 19,27 \\
\hline 2014 & $202.589 .009 .699,00$ & $880.515 .554 .432,00$ & 23,01 \\
\hline 2015 & $225.076 .368 .908,94$ & $1.606 .478 .243 .312,00$ & 14,01 \\
\hline
\end{tabular}

Sumber data : data diolah (2017)

Selama kurun waktu empat tahun, rasio kemandirian keuangan Kota Mataram berada pada tingkat rata-rata $17,71 \%$, sehingga dikatakan berada pada kategori rendah. Kontribusi PAD terhadap total pendapatan APBD masih kecil dibandingkan dengan porsi pendapatan yang bersumber dari Bantuan Pemerintah Provinsi/Pusat. Kondisi ini menunjukkan bahwa pemerintah Kota Mataram masih memiliki tingkat ketergantungan yang cukup tinggi terhadap Pemerintah Provinsi/Pusat, dan belum cukup mampu mencukupi kebutuhan daerah sendiri.

\section{Rasio Aktivitas}

Rasio ini menggambarkan kebijakan pemerintah daerah dalam menetapkan prioritas alokasi belanja rutin dan belanja pembangunan secara proporsional. Semakin tinggi persentase anggaran yang dialokasikan untuk belanja rutin berarti persentase belanja investasi (belanja pembangunan yang digunakan untuk menyediakan sarana dan prasarana layanan publik cenderung semakin kecil. Rasio ini diformulasikan sebagai berikut:

Tabel 7. Aktifitas Pengelolaan Keuangan Daerah Kota Mataram TA. 2012 - 2015

\begin{tabular}{|c|c|c|c|c|c|}
\hline \multirow{2}{*}{ Tahun } & \multirow{2}{*}{ APBD } & \multicolumn{2}{|c|}{ Belanja } & \multicolumn{2}{c|}{$\begin{array}{c}\text { Rasio Aktifitas } \\
\text { Belanja (\%) }\end{array}$} \\
\cline { 3 - 6 } & & Operasi & Modal & Operasi & Modal \\
\hline 2012 & $740.283 .006 .976,00$ & $604.854 .007 .844,00$ & $135.428 .999 .132,00$ & 81,71 & 18,29 \\
\hline 2013 & $883.521 .845 .035,00$ & $702.652 .933 .101,00$ & $180.868 .911 .934,00$ & 79,53 & 20,47 \\
\hline 2014 & $1.044 .355 .803 .030,95$ & $812.153 .650 .793,00$ & $232.202 .152 .237,00$ & 77,77 & 22,23 \\
\hline 2015 & $1.188 .685 .851 .689,10$ & $910.198 .162 .103,18$ & $278.487 .689 .586,00$ & 76,57 & 23,43 \\
\hline
\end{tabular}

Sumber data : data diolah (2017) 
Berdasarkan tabel 7 rasio aktifitas belanja Kota Mataram pada komponen belanja operasi berada pada tingkat rata-rata $78,89 \%$ sementara pada komponen belanja modal berada pada tingkat rata-rata $21,11 \%$, angka ini menunjukkan bahwa rasio belanja operasi lebih tinggi dari rasio belanja modal. Kondisi tersebut menunjukkan bahwa Pemerintah Kota Mataram lebih memprioritaskan alokasi dana yang lebih besar pada belanja operasi, tingginya belanja operasi mengakibatkan semakin berkurangnya porsi alokasi belanja modal dimana dana tersebut diperuntukkan bagi penyediaan sarana prasarana ekonomi masyarakat maupun layanan publik.

\section{Rasio Pertumbuhan}

Pengukuran rasio pertumbuhan bertujuan untuk melihat seberapa besar kemampuan Pemerintah Daerah dalam mempertahankan dan meningkatkan keberhasilan yang telah dicapai dari periode ke periode tahun berikutnya. Dengan mengetahui pertumbuhan PAD, maka dapat dilakukan evaluasi terhadap potensipotensi daerah yang perlu memperoleh perhatian. Semakin tinggi persentase pertumbuhan PAD, maka semakin besar kemampuan Pemerintah Daerah dalam mempertahankan dan meningkatkan keberhasilan yang dicapai pada setiap periode Tahun Anggaran. Rasio ini diformulasikan sebagai berikut:

Tabel 8. Rasio Pertumbuhan APBD Kota Mataram TA. 2012 - 2015 (dalam persentase)

\begin{tabular}{|c|c|c|c|c|}
\hline Tahun & $\begin{array}{c}\text { Rasio } \\
\text { Pertumbuhan } \\
\text { PAD (\%) }\end{array}$ & $\begin{array}{c}\text { Rasio Pertumbuhan } \\
\text { Pendapatan (\%) }\end{array}$ & $\begin{array}{c}\text { Rasio Pertumbuhan } \\
\text { Belanja Tidak } \\
\text { Langsung (\%) }\end{array}$ & $\begin{array}{c}\text { Rasio Pertumbuhan } \\
\text { Belanja Langsung } \\
(\%)\end{array}$ \\
\hline 2013 & 45,89 & 14,65 & 16,17 & 33,55 \\
\hline 2014 & 44,83 & 25,09 & 15,58 & 28,38 \\
\hline 2015 & 25,91 & 9,77 & 12,07 & 19,93 \\
\hline
\end{tabular}

Sumber data : data diolah (2017)

Pertumbuhan belanja pada komponen belanja operasi mengalami penurunan setiap tahun anggaran, tahun 2013 sebesar 16,17\%, tahun 2014 sebesar $15,58 \%$ dan pada tahun 2015 sebesar 12,07\%. Sementara pada komponen belanja modal juga menggambarkan kondisi yang sama yakni terjadi penurunan setiap tahun anggaran dimana pada tahun 2013 sebesar 33,55\%, tahun 2014 sebesar $28,38 \%$ dan pada tahun 2015 sebesar 19,93\%.

\section{Rasio Kinerja Keuangan}

Berdasarkan hasil perhitungan rasio-rasio keuangan diatas, maka Kinerja Keuangan Pemerintah Daerah Kota Mataram Tahun Anggaran 2012-2015 dirangkum pada Tabel 9 sebagai berikut: 
Tabel 6. Hasil Perhitungan Rasio Kinerja Kota Mataram TA. 2012-2015 (dalam persentase)

\begin{tabular}{|l|r|r|r|r|r|}
\hline \multirow{2}{*}{\multicolumn{1}{|c|}{ Keterangan }} & \multicolumn{4}{|c|}{ Tahun Anggaran } & \multirow{2}{*}{$\begin{array}{c}\text { Rata-rata } \\
\text { (\%) }\end{array}$} \\
\cline { 2 - 6 } & $\mathbf{2 0 1 2}$ & \multicolumn{1}{c|}{$\mathbf{2 0 1 3}$} & \multicolumn{1}{c|}{$\mathbf{2 0 1 4}$} & $\mathbf{2 0 1 5}$ & \multicolumn{1}{c|}{} \\
\hline Rasio Efektifitas & 104,62 & 102,04 & 102,63 & 98,11 & 101,85 \\
\hline Rasio Efisiensi & 98,01 & 102,04 & 96,42 & 99,98 & 99,12 \\
\hline Rasio Kemandirian & 14,55 & 19,27 & 23,01 & 14,01 & 17,71 \\
\hline Rasio Aktifitas & & & & & \\
\hline - Belanja Operasi & 81,71 & 79,53 & 77,77 & 76,57 & 78,89 \\
\hline - Belanja Modal & 18,29 & 20,47 & 22,23 & 23,43 & 21,11 \\
\hline Rasio Pertumbuhan & & & & & \\
\hline - PAD & - & 45,89 & 44,83 & 25,91 & 38,88 \\
\hline - Pendapatan Daerah & - & 14,65 & 25,09 & 9,77 & 16,5 \\
\hline - Belanja Operasi & - & 16,17 & 15,58 & 12,07 & 14,61 \\
\hline - Belanja Modal & - & 33,55 & 28,38 & 19,93 & 27,29 \\
\hline
\end{tabular}

Sumber data : data diolah (2017)

\section{KESIMPULAN DAN IMPLIKASI}

\section{Kesimpulan}

Fidelius (2013) berdasarkan hasil perhitungan rasio-rasio keuangan untuk mengukur kinerja keuangan Pemerintah Daerah Kota Mataram selama kurun waktu tahun anggaran 2013-2015, maka diperoleh hasil sebagai berikut :

1. Rasio Efektifitas Kota Mataram tahun anggaran 2013-2015 dikategorikan efektif karena persentase diatas seratus, yakni sebesar 101,85\%. Tingkat persentase ini menggambarkan bahwa efektifitas Pemerintah Daerah Kota Mataram dalam merealisasikan sumber pendapatan asli daerah Sangat Efektif berdasarkan Kriteria Penilaian Efektifitas.

2. Efisiensi Kinerja Keuangan Pemerintah Daerah Kota Mataram Tahun Anggaran 2013-2015 dikategorikan Kurang Efisien karena persentase dibawah seratus, yakni sebesar 99,12\%. Persentasetingkat pencapaian tersebut menggambarkan bahwa Pemerintah Daerah Kota Mataram mengeluarkan biaya yang lebih besar dalam pemungutan PAD untuk menghasilkan output (hasil) serta menunjukkan efisiensi pengelolaan keuangan daerah yang belum optimal.

3. Kemandirian pengelolaan keuangan Pemerintah Daerah Kota Mataram Tahun Anggaran 2013-2015 dikategorikan masih Rendah, dengan tingkat rata-rata 17,71\%. Pemerintah Daerah Kota Mataram masih memiliki tingkat ketergantungan yang tinggi terhadap Bantuan Pemerintah Provinsi/Pusat.

4. Kinerja Keuangan Pemerintah Daerah Kota Mataram Tahun Anggaran 2013-2015 berdasarkan perhitungan aktifitas pengelolaan keuangan daerah, masih Rendah. Pemerintah Daerah Kota Mataram lebih memprioritaskan alokasi Belanja Operasi dengan tingkat rata-rata 78,89\% dibandingkan Belanja Modal dengan tingkat ratarata $17,71 \%$. 
5. Kinerja Keuangan Pemerintah Daerah Kota Mataram Tahun Anggaran 2013-2015 berdasarkan perhitungan pertumbuhan pengelolaan keuangan daerah dapat dikategorikan Kurang Baik, karena terjadi penurunan PAD setiap tahun selama kurun waktu perhitungan tahun anggaran, sementara Pendapatan Daerah juga dikategorikan Sedang, tahun 2014 sebesar 14,65\%, meningkat tahun berikutnya, yakni tahun 2014 sebesar $25,09 \%$ dan menurun cukup tajam pada tahun berikutnya tahun 2015, yakni sebesar $9,77 \%$.

\section{Saran}

Berdasarkan analisis diatas, maka saran yang dapat diberikan pada Pemerintah Daerah Kota Mataram terkait kinerja pengelolaan keuangan daerah antara lain sebagai berikut :

1. Mempertahankan tingkat efektifitas serta berupaya meningkatkan efisiensi pengelolaan keuangan daerah. Realisasi penerimaan daerah harus tetap lebih besar dari target yang ditetapkan.

2. Optimalisasi perolehan PAD melalui penggalian sumber-sumber baru penerimaan daerah kendati jumlah bantuan dana dari Pemerintah Provinsi maupun Pemerintah Pusat masih cukup besar.

3. Memperbesar alokasi Belanja Modal yang berhubungan dengan penyediaan sarana prasarana ekonomi serta layanan publik agar dapat semakin meningkatkan kesejahteraan masyarakat daerah Kota Mataram. 


\section{DAFTAR PUSTAKA}

Amin Widjaya Tunggal. (1995). Kamus Akuntansi Manajemen Kontemporer. PT Rineka Cipta. Jakarta

BPS. (2015), NTB Dalam Angka. BPS Mataram.

Fidelius. (2013). Analisis Rasio Untuk Mengukur Kinerja Pengelolaan Keuangan Daerah Kota Manado. Jurnal EMBA. Vol. 1 No. 4 ISSN 2303-1174, http://ejournal.unsrat.ac.id/index.php/emba/article/view/3418. Hal. 2088-2096

Pemerintah Republik Indonesia. Peraturan Pemerintah Nomor 58 Tahun 2005 tentang Pengelolaan Keuangan Daerah. Jakarta.

Pemerintah Republik Indonesia. Peraturan Pemerintah Nomor 71 Tahun 2010 tentang Standar Akuntansi Pemerintahan. Jakarta.

Susanto, Hery. (2014). Analisis Perkembangan Kinerja Keuangan Daerah Dalam Upaya Mendukung Pelaksanaan Otonomi Daerah Di Provinsi Nusa Tenggara Barat. repository.ut.ac.id

Susanto, Hery. (2015). Prediksi Kemungkinan Financial Distress Pada Pemerintah Daerah Menggunakan Analisis Rasio Keuangan. Buku Program Seminar Nasional FEKON 2015.Fakultas Ekonomi Universitas Terbuka. Jakarta

Tinangon, Suoth dkk. (2016)Pengukuran Efisiensi dan Efektifitas Pengelolaan Keuangan Daerah Pada Dinas Pengelola Keuangan, Pendapatan dan Aset (DPKPA) Kabupaten Minahasa Selatan. Jurnal EMBA Vo.4 No.1 Maret 2016 ISSN 2303-1174.Hal. 613-622.

92 | Analisis Rasio Keuangan Untuk Mengukur Kinerja Keuangan... 